\title{
Populist authoritarian neoliberalism in Brazil: making sense of Bolsonaro's anti-environment agenda
}

\author{
Sierra Deutsch ${ }^{1}$ \\ University of Zürich, Switzerland \\ Wageningen University, the Netherlands
}

\begin{abstract}
In Brazil, the looming threat of mass extinction has prompted increasingly exceptional measures to protect sensitive biomes. At the same time, such measures threaten to curtail capitalist expansion and thus Brazil's neoliberal model of economic development. Jair Bolsonaro's 2018 presidential campaign responded to these threats by fueling anti-environment sentiments and anti-environmentalist enmity. Once inaugurated, he immediately began the work of dismantling national environmental governance structures. Yet his strategies for doing so are often masked by what this article describes as a 'firehouse effect', where his tactics appear chaotic, confused, and lacking any particular goal. The article uses a combination of interviews with 35 environmental experts, participant observation, and a review of secondary sources to zoom in on Bolsonaro's anti-environmentalism within the context of the contemporary turn toward populist authoritarian neoliberalism. By focusing on how Bolsonaro's policies serve to weaken protective environmental measures that limit capitalist extraction, the article unearths the major anti-environment strategies of the Bolsonaro administration. This framework thus allows us to see through the 'firehouse effect' to make some sense of Bolsonaro's methods, further building on emerging research on the political ecologies of the contemporary populist authoritarian neoliberal turn. Moreover, the article shows the utility of applying a generalized populist authoritarian neoliberal framework to a particular context in order to identify its local processes and specificities.
\end{abstract}

Keywords: Populist authoritarian neoliberalism, environmental governance, Bolsonaro, Brazil, 'firehouse effect'

\section{Résumé}

Au Brésil, la menace imminente d'extinction massive a suscité des mesures de plus en plus exceptionnelles pour protéger les biomes sensibles. Simultanément, de telles mesures menacent de freiner l'expansion capitaliste et donc le modèle néolibéral de développement économique du Brésil. La campagne présidentielle de Jair Bolsonaro en 2018 a répondu à ces menaces en alimentant les sentiments anti-environnementaux et l'inimitié anti-environnementaliste. Une fois inauguré, il a immédiatement commencé à démanteler les structures nationales de gouvernance environnementale. Pourtant, ses stratégies pour y parvenir sont souvent masquées par un « effet de diversion », où ses tactiques semblent chaotiques, confuses et sans objectif particulier. L'article utilise une combinaison d'entretiens avec 35 experts en environnement, la participation et l'observation en 2019, et un examen des sources secondaires pour se concentrer sur l'anti-environnementalisme de Bolsonaro dans le contexte du néolibéralisme autoritaire populiste. En se concentrant sur la façon dont les politiques de Bolsonaro affaiblissent les mesures de protection environnementales qui limitent l'extraction capitaliste, l'article met au jour les principales stratégies anti-environnementales de l'administration. Ce cadre nous permet de voir à travers « l'effet de diversion » pour donner un sens aux méthodes de Bolsonaro, en s'appuyant sur les recherches

\footnotetext{
${ }^{1}$ Dr. Sierra Deutsch, Senior Scientist and Affiliate Member of the University Research Priority Programme (URPP) on Global Change and Biodiversity, University of Zürich, Switzerland. E-mail: sierra.deutsch "at" geo.uzh.ch. Orcid ID: https://orcid.org/0000-0002-6659-6092. The research for this project was conducted while Dr. Deutsch was a Postdoctoral Researcher at Wageningen University, Netherlands. Acknowledgements: I am indebted to the 35 participants who contributed to this project through interviews and casual conversations. Thanks to Bram Büscher, Thomas Kiggell, and the participants of the Crisis Conservation workshop held from 5-9 October 2020, as well as to Ananda Siddhartha and two anonymous reviewers. This work was funded by the Dutch Research Council, via the NWO-VIDI project of Prof. Bram Büscher (grant nr 425-14-001). This is the seventh article in Bram Büscher (ed.). 2021. "Political ecologies of extinction", Special Section of the Journal of Political Ecology 28: 696-888.
} 
émergentes sur les écologies politiques du tournant néolibéral autoritaire populiste contemporain. De plus, l'article montre l'utilité d'appliquer un cadre généralisé pour rechercher les processus locaux et les spécificités du néolibéralisme autoritaire populiste.

Mots-clés: néolibéralisme autoritaire populiste, gouvernance environnementale, Bolsonaro, Brésil, « effet de diversion »

\section{Resumo}

No Brasil, a iminente ameaça de extinção em massa tem levado a medidas cada vez mais excepcionais para proteger biomas sensíveis. Ao mesmo tempo, tais medidas ameaçam restringir a expansão capitalista e, portanto, o modelo neoliberal de desenvolvimento econômico do Brasil. A campanha presidencial de Jair Bolsonaro de 2018 respondeu a essas ameaças alimentando sentimentos anti-ambientais e inimizade antiambientalistas. Uma vez inaugurado, deu início imediato ao trabalho de desmontagem das estruturas nacionais de governança ambiental. No entanto, suas estratégias para fazer isso são frequentemente disfarçadas pelo que este artigo descreve como um 'efeito firehouse', em que suas táticas parecem caóticas, confusas e sem um objetivo específico. O artigo usa uma combinação de entrevistas com 35 especialistas ambientais, observação participante e uma revisão de fontes secundárias para analisar o anti-ambientalismo de Bolsonaro no contexto da virada contemporânea em direção ao neoliberalismo autoritário populista. Focando em como as políticas de Bolsonaro servem para enfraquecer as medidas de proteção ambientais que limitam a extração capitalista, o artigo demonstra as principais estratégias anti-ambientais do governo Bolsonaro. Este quadro permite-nos assim ver através do 'efeito firehouse' para dar algum sentido aos métodos de Bolsonaro, construindo ainda mais a pesquisa emergente sobre as ecologias políticas da virada neoliberal autoritária populista contemporânea. Além disso, o artigo mostra a utilidade de aplicar um quadro neoliberal autoritário populista generalizado a um contexto particular, com o fim de identificar seus processos e especificidades locais.

Palavras-chave: Neoliberalismo populista autoritário, governação ambiental, Bolsonaro, Brasil, 'efeito firehouse'

\section{Introduction}

The Amazon rainforest is the largest and most biodiverse tropical rainforest in the world, with $60 \%$ falling within Brazilian borders. Although the rainforest is most likely what comes to mind when people contemplate environmental politics in Brazil, the country is home to two other important biodiversity hotspots - the Atlantic Forest and the Cerrado (Myers et al. 2000). The relatively high rate of habitat loss in all three biomes - the latter up to and over $90 \%$ - has stoked a deep sense of urgency to curtail deforestation in Brazil, with conservationists using a combination of surveillance via satellite (Voiland 2019) and legal structures (Jung et al. 2017) to limit extractive practices in these biomes.

In what has been referred to as a judicial-parliamentary coup, Brazil's former president Dilma Rousseff of the Worker's Party (PT) was impeached in 2016 (Saad-Filho and Boffo 2020). And after the failure of her successor (and former vice president) Michel Temer's administration to address a deepening economic crisis, Luiz Inácio Lula da Silva (aka Lula) appeared likely to win the 2018 election. A founding member of the PT, Lula had previously served as president from 2003-2011 and is widely regarded as one of Brazil's most popular presidents (Saad-Filho and Boffo 2020). However, in a continued attempt to take down the PT, Lula was arrested in April of 2018 under charges of corruption (Wilkinson 2018). ${ }^{2}$ Taking advantage of the political unrest associated with corruption scandals and the economic crisis, Jair Bolsonaro, a retired military officer and member of the conservative Social Liberal Party, ran a contentious and polarizing campaign steeped in a politics of enmity towards the environment and 'others'. ${ }^{3}$

In January 2019, Bolsonaro was inaugurated as Brazil's president. Congruent with Brazil's agribusiness and associated interest groups, he insisted that Brazil's economic failures are, amongst others, a result of the

\footnotetext{
${ }^{2}$ Lula was released in November 2019, the charges were later annulled, and the presiding judge Sergio Moro was found to be biased by the Supreme Court (Brito 2021).

${ }^{3}$ As McCarthy (2019) notes, the distinction of internal and external 'others' (e.g. immigrants and racialized minorities) as enemies of progress is a common tactic of populist authoritarian neoliberal leaders and assists the justification of the dissolution of democratic protections, norms, and institutions.
} 
measures taken to combat biodiversity loss and species extinctions. He immediately began the work of dismantling national environmental governance structures and institutions. His anti-environment actions were so swift and numerous that the press had difficulty deciding which ones to headline (Gonzales 2019). For example, when Bolsonaro's initial plans to merge the Ministry of Environment (MMA) with the Ministry of Agriculture, Livestock, and Food Supply (MAPA) met opposition (Casado and Londoño 2019), he instead appointed Ricardo Salles ${ }^{4}$ as head of the MMA. Salles, who was convicted of altering an environmental protection plan to benefit extractive industry as former head of a São Paulo state environmental agency, went to work turning the MMA into a pro-agribusiness ministry (Schipanii and Harris 2019), thus "answering the Rural Caucus' interests" (Environmental Nongovernmental Organization [ENGO] employee specializing in public policy, July 2019). Around the same time, Bolsonaro announced plans to move environmental licensing to a self-regulated scheme (Gonzales 2019). On the day of his inauguration, Bolsonaro issued a presidential decree to "supervise, coordinate, monitor and accompany the activities and actions of international organizations and nongovernmental organizations (NGOs) in the national territory." As part of this initiative, Salles immediately suspended all partnerships between NGOs and federal environmental agencies in Brazil, pending a review of all such partnerships (Stargardter 2019).

Over two years later, there continue to be signs that Bolsonaro is weakening environmental agencies, easing and privatizing environmental regulation, and diverting environmental funding to agribusiness (Branford and Torres 2021; Escobar 2021; Reuters 2021). Yet his attempts to do so have often seemed chaotic, disorganized, and haphazard, creating the appearance of a lack of strategy. ${ }^{5}$ In part, this is due to his conflicting declarations of his love for the environment and his record of dismantling protective measures for that same environment (Fox and Lang 2019). But this perception is also due to his penchant for issuing statements that are overwhelmingly falsifiable (Aos Fatos 2019) and presidential decrees on actions that are not possible nor legal (Coletta and Faria 2019; Spring 2019a; The Associated Press 2019). Also contributing to the perception of a lack of strategy, Bolsonaro is known for 'shooting from the hip.' In his first six months in office, he issued 202 decrees compared to 94 and 174 for the two presidents before him (Harris and Schipanii 2019). From an outside observer's perspective, his actions indicate a high degree of incompetence. Yet the net effect has been that Bolsonaro has succeeded in weakening environmental governance structures in Brazil (Ferrante and Fearnside 2019; Spring 2019b).

Although the rapid ascendance of Bolsonaro came as a surprise to many, it is consistent with the more general recent turn toward populist authoritarian neoliberalism across the globe. As is the case in Brazil, this trend is widely recognized as emerging from the continued failure of neoliberal reforms to address problems of growing socioeconomic inequality, unemployment, and poverty following the 2008 economic crisis (Bruff and Tansel 2019b; Fabry and Sandbeck 2019b; McCarthy 2019). Yet there is some debate on how the shift to neoliberal authoritarianism unfolds and few studies that have examined this shift have focused their analysis on environmental deregulation. Moreover, although such works are beginning to emerge, few have sought to understand the role of antics (seemingly random and erratic behaviors and actions) in masking this shift. In this article, I address these gaps by examining Bolsonaro's anti-environmentalism within the context of the contemporary turn toward populist authoritarian neoliberalism. I do so by going directly to environmental experts, including those in academia, government agencies, and NGOs.

My reasoning for this approach was that, regardless of how participants felt personally toward Bolsonaro, environmental experts would presumably have reliable knowledge on the anti-environmental effects of Bolsonaro's policies. Building on this knowledge, I argue that there are at least five major strategies that can be identified in Bolsonaro's antics and that the 'firehouse effect' works to mask these. The strategies include the 'skeletonizing' of environmental administrative bodies, dissolution of CONAMA and other civic spaces,

\footnotetext{
${ }^{4}$ At the time of the latest draft of this article, Salles recently resigned after facing illegal logging probes. He was replaced by a $20+$ year veteran agribusiness lobbying board member, Joaquim Alves Pereira Leite (Ennes 2021).

${ }^{5}$ In this article I use the term 'strategy' to refer to an overall plan for accomplishing specific goals. I thus use the term interchangeably to describe Bolsonaro's 'master plan' of removing barriers to capital accumulation, as well as his specific sets of plans for achieving this goal (e.g. 'skeletonizing' of environmental bodies). I use the term 'tactic' to refer to specific actions that are deployed as part of a strategy.
} 
reorganizing within the ministries, defunding of NGOs and federal universities, and cooptation of exceptional environmental measures in times of crisis. I describe each of these in the below sections. Before I get to these, however, I briefly summarize the situation in Brazil and review the literature on political ecologies of authoritarian neoliberalism and the strategies employed by authoritarian neoliberal leaders with respect to the environment.

\section{Extinction, exception, and enmity in Brazil}

In recent history, Brazil was widely acknowledged as a global leader in combatting climate change and species extinctions (Branford and Borges 2019; Casado and Londoño 2019; Trinkunas 2014; Viscidi and Graham 2019). Through a combination of measures that included stricter legislation, law enforcement, and monitoring and surveillance to crack down on illegal logging and support reforestation, Brazil was able to reduce its deforestation rate by around 80\% between 2005 and 2012, among other environmental successes (Silva Junior et al. 2021). At the same time, the measures that led to these results were often criticized as being too restrictive, in terms of regulations on land use for Brazil's agricultural outputs (Arsenault 2017). For example, agricultural and ranching businesses with unpaid environmental fines were prevented from receiving government subsidies until settling their debt, municipalities with high rates of illegal deforestation were "blacklisted", and the network of Protected Areas was expanded (Carvalho et al. 2019).

Recently, the government began to implement the Cadastro Ambiental Rural (CAR), a registry that was set up to track compliance with the part of the Brazil's Forest Code ${ }^{6}$ that requires specific percentages of private land to be set aside for conservation (the percentage varies with location). Although Philippe Le Billon highlights how CAR has led to land grabbing by agribusinesses in some cases (Le Billon 2021), conservationists have found it to be a particularly important tool for establishing wildlife corridors, which are tracts of land that connect isolated forest patches to offset the effects of habitat fragmentation, one of the primary drivers of extinction (Crooks et al. 2017). To help ensure compliance with the Forest Code, CAR registrants are monitored by Brazil's National Institute for Space Research (INPE), which has made extraordinary advances in tracking deforestation through satellite imagery, allowing for more efficient and targeted responses to illegal logging and land clearing (Assunção, Gandour and Rocha 2013; Assunção and Rocha 2019; Puthuparambil 2019). All of these exceptional measures have been important for tackling high rates of deforestation and species extinctions in Brazil.

While many of the restrictions on extractive practices and land use in Brazilian forests were eased by the 2012 modifications to Brazil's Forest Code, several politicians still claim that the exceptional environmental regulations in Brazil are at the root of the deepening economic crisis (Arsenault 2017; Nugent 2021). Among these is Jair Bolsonaro, who in addition to blaming corruption for Brazil's economic woes has described Brazil's environmental protection as "suffocating" economic growth (Rachman, Blasina and Schipani 2019; Viscidi and Graham 2019) and believes that "environmental politics (is getting) in the way of business" (ENGO employee specializing in public policy, April 2019). Bolsonaro is staunchly pro-business, known for his disregard for environmental regulations (Spring and Eisenhammer 2019) and science (Escobar 2021; Tollefson 2018), and for making racist, misogynistic, homophobic remarks (Borba 2020; Kaul 2021; Lehman 2018; Da Silva and Larkins 2019). He garnered popular attention during the presidential campaign by promising to fix corruption and perceived threats to the national economy of Brazil with swift, decisive, and uncompromising action (Hunter and Power 2019; Tollefson 2018). He captured the economic angst of the 'ordinary' citizen and directed it toward internal and external racialized and 'ideological' 'others' (Borba 2020; D. Phillips 2019a; Tollefson 2018). These ideological others include all those who would get in the way of economic expansion through capital accumulation, especially environmental and social advocates, and particularly scientists that support these advocates' claims (Acebes, Wilkinson and Téllez-Chávez 2019; Pettorelli et al. 2019; Tollefson 2018). His campaign was steeped in anti-environment enmity with direct attacks on prominent Brazilian environmental figures (Acebes, Wilkinson and Téllez-Chávez 2019) and promises to roll back environmental regulations and enforcement to free up land for development and extraction (Bogliolo 2019; Casado and Londoño 2019; Saad-

\footnotetext{
${ }^{6}$ The Forest Code of 1965 is the country's main mechanism for forest protection on private lands.
} 
Filho 2018). Once in office, he has pursued his campaign promises with fervor and total disregard for the Constitution and legislative processes, often attempting to dismantle and eradicate legal barriers to his agenda (Coletta and Faria 2019; Observatório do Clima 2020).

For these and other reasons, many analysts recognize Bolsonaro as a populist authoritarian neoliberal (McCarthy 2019; Saad-Filho 2018). At the same time, his antics make his tactics seem so chaotic and unplanned that many environmental experts have expressed difficulty with determining whether he has any strategy, or if he is just 'shooting from the hip' (Cowie, 2018; Harris and Schipanii, 2019; and as demonstrated in Section 4). Moreover, since this 'shooting from the hip' has been given so little attention in the literature on populist authoritarian neoliberal environmental governance, there is no guide for understanding how such behavior may serve to mask strategies. As the home of some of the most important areas in the world for biodiversity and climate stability, Bolsonaro's campaign promises to eliminate environmental restrictions on extraction are alarming. Moreover, it seems important to understand the anti-environmentalism of populist authoritarian neoliberal leaders and how it relates to their strategies if we hope to develop effective counterstrategies. Next, I review the literature on political ecologies of authoritarian neoliberalism and the environmental strategies of populist authoritarian neoliberals to situate Brazil and Bolsonaro within this broader context and argue that this allows us to start making sense of his antics.

\section{Political ecologies of authoritarian neoliberalism}

The rise of countries turning toward an 'authoritarian fix' (Bruff 2014) is rapidly becoming a focus of study and cause for alarm. Putin in Russia and Xi in China in 2012, Modi in India and Erdoğan in Turkey in 2014, Duterte in the Philippines in 2016, Battulga in Mongolia and Trump in the US in 2017, Bolsonaro in Brazil in 2019, and, most recently as of this writing, Johnson in the UK in 2019. Each of these countries has its own particularities and histories that led to the election of populist neoliberal 'strongmen.' But what they have in common is their political economic trajectories characterized by the failure of neoliberal reforms to address deepening crises of socioeconomic inequality, unemployment, and poverty (Brown 2020; Fabry and Sandbeck 2019a; Fraser 2017). Although many scholars have written about these trends and their relationship to the contemporary populist authoritarian turn, Ian Bruff (2014) is one of the first analysts to define 'authoritarian neoliberalism' and use it as a theoretical framework through which to understand the post-2008 global trend toward 'strongman' leadership (Fabry and Sandbeck 2019a).

Although the populist authoritarian strand of the aforementioned turn seems relatively uncontested in the academic literature, the neoliberal strand is not always so clear. For example, the determined attempts of leaders such as Trump and Johnson to exit international partnerships and free trade agreements may be interpreted as a withdrawal from neoliberalism by some. However, several scholars have argued that such attempts at protectionism do not signal a departure from neoliberalism (Bell and Christoph 2020; Cornelissen 2021; Cozzolino 2018; Fuchs 2017). On the contrary, analysts such as Wraight (2019) have honed in on this 'neoliberal protectionism' to demonstrate how Trump's trade policy (2017-2021) was actually a return to past neoliberal practices. Such practices are aimed at forcing other nations to fall into line with their market-based logic, with coercion operating through "the blunt use of protectionism or threats of protectionism. . . as a device by which powerful nations, like the US, can insist on the imposition of market driven norms" (ibid. p. 741). This, he argues, was evident in Trump's trade war with China, launched to address the threat that China's industrial policies pose to the global economic order. Meanwhile, Johnson's protectionism is driven by a need to release restrictions on UK trade (rather than to impose restrictions on other nations). As Bell (2019) argues, Johnson and other UK neoliberal leaders favored exiting the EU because they believed the regulations were too restrictive and thus harming unfettered economic growth. While these strategies may appear to reflect different goals on the surface, Johnson and Trump are (or were) pursuing the same ultimate goal as Bolsonaro, removing restrictions to capital accumulation.

In addition to discussions on what characterizes neoliberal leaders, the utility of using a neoliberal framework to analyze seemingly disparate actors, contexts, and cases such as the ones above, has been the subject of ongoing academic debate (see Cahill et al., 2018 and Peck and Theodore, 2019 for summaries). This debate usually occurs as two supposedly polar opposites, where scholars tend toward one of "the twin pitfalls 
of both monolithic fetishization, on one hand, and endless contextualization on the other" (Holmes and Cavanagh 2016, p. 201). However, Brenner and Theodore (2002) argue that 'actually existing neoliberalism' is best understood as series of processes of neoliberalizations, that interact with local realities in contextdependent ways. Thus neoliberal proponents and leaders engage different processes and strategies of neoliberalization, depending on the tools and opportunities available to them (Dawes and Lenormand 2019; Peck 2013). Following Holmes and Cavanagh, Brenner and Theodore, Peck, and others, Dawes and Lenormand (2019) attempt to find a middle ground between the two pitfalls by "accommodating a fluid and variegated appreciation of contextual difference while maintaining a structural approach that recognizes the ways in which local differences and contextually embedded forms are shaped by wider processes" (p. X). This becomes ever more important as there is clearly an increasingly authoritarian tenor to these processes; that is to say leaders of contemporary democracies are increasingly engaging in such processes without consent (whereas before there was at least the illusion of it) (Brown 2020; Bruff 2014; Peck and Theodore 2019). This article builds on this work by using a populist authoritarian neoliberal framework to tease out local manifestations of populist authoritarian neoliberal tactics that may otherwise be lost in 'endless contextualization.'

Since Bruff's (2014) foundational article on 'authoritarian neoliberalism', references to the term and its broad applications have grown - often as collaborative efforts to grapple with the problem - at multiple conferences, in edited volumes and special issues, and in stand-alone articles. Such attempts to understand and theorize authoritarian neoliberalism in all its shapes and forms have covered myriad and broad topics, but few have focused on these as they relate to the environment. There was a notable lack of such analyses in the Oxford Handbook of the Radical Right (Rydgren 2018), which contained chapters on multiple themes and connections. The environment is also missing from several other prominent works on authoritarian neoliberalism, including Cas Mudde's (2019) The Far Right today, the special issue on 'Authoritarian Neoliberalism: Philosophies, practices, contestations' in Globalizations (Bruff and Tansel 2019b), and on 'Authoritarian Neoliberalism' in Competition \& Change (Fabry and Sandbeck 2019b). This is certainly not for a lack of links between the two. Indeed, "(t)he connections between the widespread rise of authoritarian and populist leaders, administrations, and movements on the one hand and destructive trends in environmental politics and governance on the other are legion" (McCarthy, 2019, p. 305). Yet, to my knowledge, the only collaborative attempt to understand contemporary authoritarianism that includes a discussion of the environment, is the recent special issue in the Annals of the American Association of Geographers on 'Environmental governance in a populist/authoritarian era' (McCarthy, 2019).

In the introductory article to the Annals issue, McCarthy (2019) argues that:

...many contemporary authoritarian regimes are pursuing and deepening long-standing neoliberal goals with respect to the environment, removing restrictions on capitalist production by withdrawing from constraining international agreements and standards, rolling back domestic environmental protections, and appointing heads of polluting corporations to head the very agencies that are supposed to regulate those corporations. (p. 306)

Yet such practices have not occurred without dissent. And this is where authoritarian neoliberalism departs from its predecessor, 'progressive' neoliberalism. According to Bruff (2014, p. 116, emphasis in original), "(a)uthoritarian neoliberalism does not represent a wholesale break from pre-2007 neoliberal practices, yet it is qualitatively distinct due to the way in which neoliberalism's authoritarian tendencies ... have come to the fore through a shift toward constitutional and legal mechanisms and away from seeking consent for hegemonic projects." Still, a major question remains: How do these shifts occur? In other words, how does one accomplish this elimination of the need for consent without ... consent?

To answer this question, some have argued that authoritarian strategies include attempts to marginalize, discipline, and control "dissenting social groups and oppositional politics rather than strive for their explicit consent or co-optation" (Bruff and Tansel 2019a, p. 234). With respect to the environment, Acara (2019) discusses how the strategies of centralization and lack of transparency and clarity in water resource governance 
in Turkey has normalized such processes in the country in general. Mullenite (2019) demonstrates how flood control infrastructure design and management have been used in Guyana to create and maintain ethnic divisions that served to support an ethnic nationalist authoritarian regime. Arefin (2019) describes how the Egyptian state has reframed the causes of environmental disasters in ways that support the continued control of the repressive regime. Rather than acknowledging the cause of a severe flood as a failure of environmental governance and a result of climate change, the Egyptian state claimed the floods were an act of terrorism. In this way, the state is able to simultaneously relieve itself of obligations with regard to environmental governance, while creating justifications for its continued restrictions of freedoms and use of force.

Several scholars have also noted manipulation of emotions by discursively linking values with political ideologies and agendas as a primary strategy of the far right, with some examining the specific ways this strategy is deployed with respect to ideas of climate change and energy extraction (Forchtner, Kroneder and Wetzel 2018; Graybill 2019; Lockwood 2018). Still others have observed the important role that discourses and narratives around peace and security play in helping secure authoritarian power and control over environmental resources (Kantel 2019). While studies such as these on environmental governance strategies during the shift to authoritarian neoliberalism have begun to emerge, few have addressed the antics - seemingly random and erratic behaviors and actions - that often accompany these shifts. Several studies have relied on the idea of 'spectacle' to explain how Trump's antics quickly gained him popularity and secured his win at the 2016 US Presidential election (Fuchs 2017; Hall, Goldstein and Ingram 2016; Kellner 2016). Pulido et al. (2019) show how Trump's rise in the use of 'spectacular racism' corresponded to an intensification of environmental deregulation. They argue that the 'spectacular' ways in which Trump deploys his racism, amongst others, functions to effectively mask the processes of environmental deregulation as they unfold. However, few studies have gone beyond the distractive aspect of 'spectacle' to examine the sense of chaos and confusion such antics create. Nor have studies interrogated how such effects add to the difficulty of identifying specific strategies, lending assistance to 'spectacle' in masking the shift to authoritarian neoliberalism and hampering efforts to stop or reverse it.

Bolsonaro demonstrates some of the same antics characteristic of Trump's campaign and presidency, and many environmental experts have struggled to make sense of his anti-environment strategies. As discussed above and in alignment with other populist authoritarian neoliberal leaders, Bolsonaro has clearly stated that he intends to remove barriers to capital accumulation. Thus, to make sense of Bolsonaro's anti-environment strategies, I begin with the assumption that such strategies are likely to proceed with the main goal of restructuring federal governance mechanisms to eliminate barriers to capital accumulation. Antienvironmentalist enmity, then, serves as a vehicle for de-legitimizing supporters of environmental safeguards and thus becomes an insurance policy against the resurrection of impediments to unrestrained accumulation. Accordingly, by asking the question "How does each strategy accomplish the goal of removing barriers to capital accumulation?" we can begin to fit Bolsonaro's strategies into a framework that allows us to make sense of his seemingly random tactics. To begin this work, I explain how the 'firehouse effect' may make it difficult to tease out Bolsonaro's strategies, but that viewing Bolsonaro's anti-environmentalism through an authoritarian neoliberal lens helps to bring these into clear(er) focus. Thus, I outline five major strategies of the Bolsonaro administration, demonstrating how they might serve the neoliberal goal of removing barriers to capital accumulation by weakening protective environmental measures and intensifying anti-environmentalist enmity to hamper advocates' ability to fight back.

\section{Making sense of Bolsonaro's strategies}

In order to understand and track Bolsonaro's strategies with respect to the environment, I went to Brazil three times in 2019 for a total of 12 weeks to interview, and re-interview, 35 environmental experts in government agencies, academia, and environmental/socioenvironmental non-governmental organizations (ENGOs/SENGOs). My understanding of these strategies comes from these interviews, participant observation, 
and casual conversations, as well as from a review of secondary sources - particularly popular news media, which were used for verification and clarification of facts and events referred to by interviewees. ${ }^{7}$

When asked about Bolsonaro's anti-environment strategies and potential counterstrategies, the majority of interviewees relayed a sense of chaos and confusion. "People are totally lost and don't know what to do", explains an ICMBio employee (March, 2019). This includes employees in senior positions who were "kind of lost and confused and following orders." (ibid.) According to a founder of a major ENGO, Bolsonaro's strategy "changes from one day to the other without telling all of his team" as her co-founder chimes in "childish behavior" (March 2019). Another interviewee explained "We're trying to be kind of focused because there are so many threats from different directions" (ENGO employee specializing in public policy, April 2019). Even by July, the sentiment was "everybody is I think still (saying), '... This is very different. This is very strange, how do we act now?"' (SENGO executive team member, July 2019). And although several interviewees had devised ways of developing counterstrategies by October, there was still an overall sense that "we are in this completely crazy situation that things happen (all the) time ... there are so many things that happen here, like surreal things" (Director of SENGO, October 2019).

Rather than simply referring to Bolsonaro's erratic behaviors as antics, one of the interviewees referred to these as the 'firehouse strategy', where innumerable 'fires' are set and draw out 'fire fighters', leaving the 'firehouse' empty and the 'fire fighters' mired in chaos. Or, as the interviewee put it: ". . . (the extreme right government) say(s) lots of stupid and crazy things for people to try to address these absurdities. And then, behind, they make very important changes in law" (ENGO employee specializing in public policy, April 2019). It mirrors Trump's strategy of spectacle as described above, yet it is unclear whether Bolsonaro is engaging such a strategy with intention. ${ }^{8}$ Such an analysis is beyond the scope of this article, but the effect is nonetheless notable, and goes beyond spectacle as it carries a significant component of confusion. Thus, I argue that the 'firehouse effect' is brought on by at least six behaviors of a leader:

1) making statements that conflict with actions;

2) making statements about intent to do something, then retracting the statement shortly afterwards;

3) lying or making misleading statements;

4) issuing statements and/or decrees that clearly reveal an intent to perform illegal and/or unconstitutional acts;

5) making offensive statements about marginalized categories of people; and

6) doing all of these things in constant and rapid succession.

The composite of these elements is often mistaken for incompetence, but whether or not incompetence is at play, the effect is that it makes it difficult to identify particular strategies.

Bolsonaro's 'firehouse effect' is rich with examples of all of the above elements. His statements about the environment frequently conflict with his actions, such as his profession of "profound love and respect for the Amazon" (T. Phillips 2019) and his declaration that "protecting the forest is our duty, acting to combat illegal deforestation and any other criminal activities that put our Amazon at risk" (Fox and Lang 2019), while simultaneously weakening protection of the Amazon, leading to the highest deforestation rate in over a decade

7 To be cited, popular news media sources had to have an Ad Fontes reliability score of 40 or above (see www.adfontesmedia.com), a Media Bias/Fact Check factual reporting assessment of "high" (see www.mediabiasfactcheck.com), or were recommended by interviewees as a known reliable news source in Brazil (e.g. Folha de S. Paulo).

${ }^{8}$ At a ministerial meeting in May 2020, the minister of environment (Salles) suggested that the administration take advantage of the opportunity of the media's preoccupation with the COVID-19 crisis, as the numbers of cases and deaths continued to surge in Brazil, to work on environmental deregulation "while we are at this moment of tranquility in terms of press coverage" (Bragança and Menegassi 2020; Uribe 2020). This suggests that the administration is both aware of the political advantage of distraction and more than willing to exploit such opportunities. 
(Climainfo 2019; Uribe, Coletta and Moreira 2019). As mentioned above, he has also said that he would merge the ministries of environment and agriculture, later deciding not to (Casado and Londoño 2019; globo.com 2018). He stated an intent to leave the Paris agreement, but later withdrew his statement (Viscidi and Graham 2019). Aos Fatos, an independent fact-checking agency in Brazil, analyzed 149 statements made by Bolsonaro in the first 10 weeks of his presidency and found that $55 \%$ of those statements "were completely false or had some degree of error" (Aos Fatos 2019). He has attempted to move the demarcation of indigenous lands from the Ministry of Justice to the Ministry of Agriculture even after Congress rejected the move (Fox and Lang 2019), issued a decree to ease restrictions on guns (Harris and Schipanii 2019), and attempted to abolish the majority of civic spaces within the administrative structure for public participation (Decree No. 9,759 of April 11, 2019). All of these were rejected by either Congress or the Supreme Court as unconstitutional (Arbex 2019; Coletta and Faria 2019; Harris and Schipanii 2019). Bolsonaro's racist, misogynistic, and homophobic comments are now well known (Borba 2020; Kaul 2021; Lehman 2018; Da Silva and Larkins 2019). Although it remains unproven, several journalists have suggested that, as Trump did, Bolsonaro uses outrageous and offensive comments to distract from scandals, such as when his son was accused of money laundering (see for example Phillips, 2020; Romm, 2019).

All these elements of the 'firehouse effect' are mobilized constantly and in rapid succession, earning Bolsonaro his reputation of 'shooting from the hip' (Cowie 2018; Harris and Schipanii 2019). In the first three weeks of his presidency alone, the Bolsonaro administration announced restrictions on international NGOs and all NGO partnerships with environmental civil service agencies, moved the responsibility of the demarcation of indigenous lands from the Ministry of Justice to the Ministry of Agriculture, eliminated the responsibility of ensuring LGBT rights from the Human Rights Ministry, issued a decree to reduce national ministries from 29 to 22, reviewed government contractors and fired those who didn't share the political ideologies of Bolsonaro's administration, scaled back environmental enforcement, pulled out of a UN Migration accord with 160 signatories, eased restrictions on gun ownership, and legalized the use of 131 previously restricted pesticides. I suggest that this rapid deployment of anti-advocate measures are masked, at least initially, as advocate social movements ${ }^{9}$ try to keep up and triage responses, by the multiple ways Bolsonaro deploys elements of the 'firehouse effect' as he dismantles measures meant to protect the environment, as well as human rights.

Below, to break through the 'firehouse effect', I explore five of Bolsonaro's anti-environment strategies and how these meet the two goals of weakening of protective environmental measures and delegitimizing supporters of those measures. Some of the strategies may not necessarily have been deployed as solely antienvironmental (i.e. they may be more anti-regulation in general), but certainly have at least a partial antienvironment agenda and are thus still notable.

\section{'Skeletonizing' environmental administrative bodies}

When Bolsonaro initially proposed to eliminate the Ministry of Environment (MMA), collapsing it into the Ministry of Agriculture (MAPA), he was met with resistance not just from the opposition, but also by his constituents who thought it was a bad idea (Rocha, 2020; ENGO employee specializing in public policy, April 2019). Without at least the appearance of environmental care, many in the sector were afraid to lose their competitive edge in the global market, especially for beef and soy (Casado and Londoño 2019). So Bolsonaro decided to keep the MMA. On paper at least (Observatório do Clima 2020). But his administration eliminated two departments in charge of climate change and mitigation, as well as one tasked with fighting deforestation (Escobar 2019a) and moved the Brazilian Forest Service (SFB), which includes the rural environmental registry (CAR) to MAPA (Observatório do Clima 2020) under the supervision of Valdir Colatto, who worked against the Forest Code (Gonzales 2019). He also transferred the management of water resources to the Ministry of Regional Development (Observatório do Clima 2020). Meanwhile, Bolsonaro's new pro-agriculture minister of the environment, Ricardo Salles, was swift to demote almost all civil servant employees who held managerial,

\footnotetext{
${ }^{9}$ Here, I take the commonly accepted definition of 'social movements' in Social Movement Theory literature: "collective challenges, based on common purposes and social solidarities, in sustained interaction with elites, opponents, and authorities. This definition has four empirical properties: collective challenge, common purpose, social solidarity, and sustained interaction" (Tarrow 2011, p. 9).
} 
coordination, and leadership positions in the Ministry of Environment, as well as ICMBio - the governmental unit that provides research and monitoring of protected areas and species to guide environmental regulations and IBAMA, the governmental unit that enforces environmental regulations (Audi and Martins 2019).

The Bolsonaro administration has also been working hard at cutting the funding to ICMBio and IBAMA, with IBAMA receiving a 24\% cut in its budget and the MMA spending only \$R 1.17 million (US\$402,500) on policy planning and management in the first eight months of 2019, compared to \$R 35.6 million (US\$8.4 million) in the same period the year prior (Girardi 2019). Employees of ICMBio and its affiliated research institutions that I interviewed for this project were aware that there had been some discussion on the restructuring of ICMBio and possible elimination of several research centers but, as of October 2019, they had still not received the restructuring plans, nor the budget for 2019. Understandably, this limited their activities, with several feeling that this was an intentional move to render them ineffective. Moreover, with each of my visits to Brazil, it was clear that living under such uncertainty, where one might lose their job at any moment, was wearing down on research center employees and their resolve. Many expressed an increasing feeling of despair, and exhaustion from being in a constant state of uncertainty, to the point where they were becoming apathetic as a protection mechanism. Referencing a quote of a biologist in a report by Bernardo Esteves (2019), one of the interviewees summed up the process by declaring: "(Salles is) working like a termite. He's destroying from inside and you cannot see it from outside. And inside everything is gonna be destroyed" (ICMBio employee, July 2019). I refer to this process as the 'skeletonizing' of environmental administrative bodies, where the basic structure is left in place, but all of the 'meat', the 'muscle', has been removed.

Although such 'skeletonization' of environmental administrative bodies is not new to the neoliberal landscape and has been occurring in various contexts for some time (Peck 2001), what signifies a shift toward removal of consent (and thus the authoritarian form of neoliberalism) is the silencing of MMA employees. According to several MMA employees, many of those who dissented, were fired (if they weren't tenured) or removed from their posts and demoted and/or given positions in remote areas of Brazil (if they were tenured). Others lamented the fact that "now, (the new government) close(s) our mouth and we can't say anything about anybody" (ICMBio employee, April 2019) complete with a media blackout order, which restricted them from posting or publicizing anything about their work, including conservation successes.

Weakening of protective measures

The 'skeletonizing' of environmental administrative bodies has proven effective at weakening both the production of new protective measures and the enforcement of established ones. As of October 2019, the MMA was still $24 \%$ empty and only 21 out of 27 state superintendent positions in IBAMA remained open according to several government employees. In the first eight months of 2019, there was a $29.4 \%$ reduction in fines for illegal logging compared to the same period in 2018 (BBC News 2019a). This was not due to a decrease in illegal logging as deforestation increased 30\% in the period of August 2018 to July 2019 compared to the previous year according to Brazilian Space Research Institute (INPE), which monitors deforestation by satellite (Dwyer 2019; Vaughan 2019).

Moreover, according to several employees in ICMBio, Bolsonaro eliminated the screening process for applicants for positions in national environmental agencies, which require technical expertise and experience. Instead, he encouraged environmental military police to apply (Acebes, Wilkinson and Téllez-Chávez 2019; Observatório do Clima 2020). Their main qualification then, as one interviewee pointed out, was that they knew how to take orders without question or thought. These new directors and presidents lack both in technical expertise and strategic planning for environmental stability (Acebes, Wilkinson and Téllez-Chávez 2019). Furthermore, according to several government employees, because all of the decisions are made by these new employees, and because they take orders from above rather than base their decisions on science and technical expertise coming from below, the situation has effectively rendered the MMA and all of its affiliated institutions ineffective. 


\section{Anti-environmentalist enmity}

Once Bolsonaro began to secure the ineffectiveness of the MMA and its affiliated institutions he was then able to use this ineffectiveness as further "proof" that such institutions are not working and are, therefore, unnecessary (as described by several interviewees and in Esteves, 2019). This adds to his claims that civil servants in the advocate movement are inept and incompetent (see Acebes et al., 2019; Casado and Londoño, 2019). In response to the INPE report on deforestation, Bolsonaro attempted to discredit Ricardo Galvão, the space agency's director (Tollefson 2019). The public dispute led to Galvão resigning even though the satellite images and their associated data, which support Galvão's claims, are open and available to the public (BBC News 2019b). When he is not de-legitimizing supporters of protective measures, he accuses them of foul play, such as when he blamed NGOs for starting the Amazon fires that made international news in August 2019 (BBC News 2019b).

\section{Dissolution of CONAMA and other civic spaces}

Going hand in hand with the skeletonizing of environmental administrative bodies is the dissolution of civic spaces. In March 2019, the Bolsonaro government issued a decree to dissolve Brazil's National Councils, terminate the National Social Participation Policy, and dismantle spaces within the administrative structure for public participation. Members who thought their councils were important were told to write a letter justifying the existence of the council within 48 days and the government would decide which councils to recreate. According to several interviewees, two of the major targets of these attempts were Conservation Unit councils and the national council for the environment (CONAMA). Fortunately, the Supreme Court limited the effects of the decree to those that were not established through legal mechanisms, but civic spaces were still greatly reduced (Coletta and Faria 2019). According to a manager of a major ENGO, "In the past ... we have a way to talk with (environmental agency employees). Established places where we can talk . . . we don't have space anymore to talk" (October 2019).

CONAMA is a particularly important one of these spaces and included representatives from the state, private, and public sectors. In May 2019, the council was reduced from 96 board members to 23 and the selection process was replaced with a lottery-style draw for 13 of the board members (Acebes, Wilkinson and Téllez-Chávez 2019; Observatório do Clima 2020). Civil society lost the greatest number of seats, shifting the weight of the council towards the federal government, which maintains the ten fixed (non-lottery) positions. As one interviewee put it: "So now (the government has) a body that will issue rules and decisions in a way that interests them" (ENGO employee specializing in public policy, July 2019).

\section{Weakening of protective measures}

CONAMA is responsible for deliberating on and advising government policy with respect to the environment and natural resources. As such, it sets the standards for environmental practices of businesses and corporations. Thus, shifting the power on the council in favor of the pro-business federal government allows for environmental measures to be interpreted in favor of business. This was made particularly clear with the highly controversial removal by the council of three Resolutions meant to protect the environment from private interests in September 2020 (Guimarães 2021). Moreover, the elimination of public participation in the form of various forums and councils, ensures a lack of oversight by and accountability to the public. The dissolution of public participation is itself a weakening of protective measures, but it also ensures that the public will have a reduced role (via their representatives) in deciding which protective environmental measures will be compromised to accommodate the expansion of businesses.

\section{Anti-environmentalist enmity}

By reducing public participation in governance, restriction of access to information is justified and public representatives are forced to turn to secondary sources for updates on government discussions and operations. With Bolsonaro's history of publicly attacking environmental scientists and leaders (Angelo 2019; Tollefson 2019), this does not bode well for a balanced understanding of the actions of these guardians of protective measures. 


\section{Reorganizing within ministries}

Another tactic of the Bolsonaro administration has been to reorganize responsibilities within the ministries, especially to open up land for agricultural development and augment agribusinesses' control over land in general. Bolsonaro attempted to move the responsibility of the demarcation of indigenous lands from FUNAI (in the Ministry of Justice) to the Ministry of Agriculture (Acebes, Wilkinson and Téllez-Chávez 2019). This attempt failed. ${ }^{10}$ However, he did succeed in moving the body in charge of managing national forests, the Brazilian Forest Service (SFB), from the Ministry of Environment to the Ministry of Agriculture, as well as the management of water resources to the Ministry of Regional Development (Observatório do Clima 2020). The SFB is also responsible for the Rural Environmental Registry (CAR). Set up by the Forest Code of 2012, CAR requires a certain percentage of privately owned land to be set aside for conservation.

\section{Weakening of protective measures}

The relocation of CAR essentially means that 'the fox is guarding the hen house' as the head of the SFB, Valdir Colatto, is a member of the agriculture voting bloc and worked against the Forest Code (Gonzales 2019). Additionally, the movement of CAR and SFB has particularly significant implications for the conservation of jaguars (Panthera onca) and their habitats since conservationists, according to interviewees in ICMBio, ENGOs, and academia, have been working with landowners and CAR to coordinate conserved lands into corridors for jaguar use. According to an interviewee, who is an employee of ICMBio, the use of CAR for jaguar corridors is further confounded by Colatto's pro-hunting stance, as more farmers will have guns. Poaching of jaguars due to conflicts with farmers is one of the major threats to the large cat in many areas of Brazil (Paviolo et al. 2016). And without the ability to utilize CAR to allow for more free movement of the animals, there are few other means to mitigate conflict according to the interviewee.

\section{Anti-environmentalist enmity}

The intent behind the reorganization of ministries is clearly to allow agribusinesses to exercise control over the measures that restrict their activities (Acebes, Wilkinson and Téllez-Chávez 2019; Observatório do Clima 2020; D. Phillips 2019b). In the case of the relocation of CAR, jaguar conservationists have lost an important tool for jaguar conservation, hampering their ability to protect the jaguar from extinction. Since such processes are so complex, to the general public it may read as a simple failure of conservationists to do their jobs. Such is arguably the case with any tools for protecting nature that have been transferred to the hands of the very businesses that nature needs protecting from.

\section{Defunding of NGOs and federal universities}

The next Bolsonaran tactic actually brings us full circle in a way: the attempt to defund NGOs. On January 14, 2019 Bolsonaro's Minister of Environment Ricardo Salles shut down "all agreements and partnerships with non-governmental bodies (NGOs) which are recipients of funds managed by the MMA, IBAMA (the nation's environmental agency), ICMBio (its national park management agency), and JBRJ (the Rio de Janeiro Botanical Garden Research Institute)" (Gonzales 2019) until he could audit them all himself, another part of the 'firehouse effect.' But it turns out he couldn't legally do that with NGOs that receive international funding and after much public outcry, he walked it back to just those NGOs receiving federal funding and not those "agreements or partnerships that have been already in execution" (Gonzales 2019). Still,

\footnotetext{
10 The reason the attempt to move the demarcation of lands failed is actually because of a recent Supreme Court case that set a precedent for presidential decrees. Presidential decrees have an expiration date, where they must be reviewed and approved by the legislative branch within 120 days. What this Supreme Court case did was establish that, if a decree expires before it can be approved, then it cannot be reintroduced in the same year. And this is also where the opposition's strength lies. Not only is the legal system strong, with sympathetic judges in the Supreme Court, but most of congress members are experienced, whereas many of the rural caucus members are new and inexperienced. For presidential decrees in particular, this works strongly in the opposition's favor. One of the biggest strategies to prevent a decree from passing before its expiration date is to talk as much as you can to kill time. Unfortunately for the newbies, they saw this as an opportunity to be seen and heard. So both sides of congress are talking hundreds of presidential decrees into expiration (Acebes, Wilkinson and Téllez-Chávez 2019).
} 
he has made attempts at limiting and/or diverting international funding, such as the Amazon Fund. The Amazon Fund, set up in 2008, is an international partnership with developed nations, particularly Norway and Germany, to provide roughly \$US87 million annually "to prevent, monitor and combat deforestation, as well as to promote the preservation and sustainable use in the Brazilian Amazon" (Amazon Fund no date).

In addition to attempting to limit funding sources to NGOs, the Bolsonaro administration also took aim at funding for federal universities in late April 2019. First announcing plans to cut funding to sociology and philosophy departments, this morphed into a 30\% funding cut to Brazil's three major universities, and then a $30 \%$ cut to all federal universities (Redden 2019). The funding cuts were especially meant to target nonutilitarian disciplines in order to "focus on areas that generate an immediate return to the taxpayer, such as: veterinary, engineering, and medicine" (Bolsonaro 2019). In addition to the budget cuts, the administration also froze funding for more than 3,000 postgraduate research scholarships (Escobar 2019b).

\section{Weakening of protective measures}

According to several ENGO employees, many of the ENGOs in Brazil have been able to maintain their international funds, since such funds are not (yet) subject to government oversight. According to one interviewee in the ENGO sector, some of the ENGOs that lost funding have shifted their funding sources to Brazilian states. However, the actions of the Bolsonaro administration to dramatically redefine the rules of the Amazon Fund, particularly to restrict the use of funds by NGOs to combat deforestation and to compensate property owners for land confiscated in protected areas, has led to Norway and Germany freezing their funds (Observatório do Clima 2020). As a result, those NGOs that received funding from the Amazon Fund have had to suspend projects and reduce their staff, according to several employees of these NGOs. This inevitably has implications for their ability to combat deforestation in the Amazon.

By limiting funding to non-utilitarian disciplines in academia, the Bolsonaro administration silences the critical voices of intellectuals and by freezing funds for postgraduate research, they reduce a key source of information that drives environmental policy. Thus, defunding of federal universities serves to degrade the foundation on which protective environmental measures are built.

\section{Anti-environmentalist enmity}

When the Amazon fires raged in August 2019, increasing by 84\% over the previous year according to INPE (BBC News 2019b; Taylor 2019), the fires were widely regarded by conservationists as being attributable to the rise in deforestation to clear land for agricultural development (BBC News 2019b; Spring and Eisenhammer 2019). Bolsonaro, whose policies and rhetoric likely enabled this deforestation (Escobar 2020; Londoño and Casado 2019), indicated that environmental NGOs had intentionally set the fires to garner support and bolster funding (BBC News 2019b; Observatório do Clima 2020). When these claims were found to be unsubstantiated, he doubled down, indicating that Leonardo DiCaprio played a role in inciting the fires (Observatório do Clima 2020). While Bolsonaro's claims of the involvement of NGOs and DiCaprio in the fires was unsupported by evidence, a few cursory glances at the social media pages of environmental NGOs at the time suggests that efforts to de-legitimize them was in full swing. ${ }^{11}$

By defunding academic institutions and especially critical social science and research, the Bolsonaro administration ensures the isolation of critical social scientists and a lack of science to support their claims. This, combined with Bolsonaro's attacks on social scientists as "cultural Marxists", who are supposedly aligned with oligarchs to undermine traditional values (Redden 2019), then serves to exacerbate the animosity towards critical social scientists and environmentalists. Our group of researchers experienced this first-hand. While eating at a restaurant in Atibaia, we were approached by the owner, who had clearly had quite a few drinks. Emboldened by his intoxication, he asked what we were doing in Brazil. We explained that we were there for research, but avoided the topic we were there to study (environment and conservation). He increasingly became more aggressive, asking us what we thought of Bolsonaro. We did our best to politely avoid the questions and state that we were simply there to enjoy a pleasant meal. Eventually he very oddly set a glass bottle down on

\footnotetext{
${ }^{11}$ At the time of writing, it appears that the negative and threatening comments on social media have been brought under
} control. 
our table and let it roll off the table to smash while maintaining eye contact with us. The two men who were accompanying him urged him to step outside and get some air and, luckily for us, he did. But the whole episode served to bring the anti-intellectual and anti-environmentalist enmity into full focus. It was clear that we, and any intellectual environmentalists, were meant to feel intimidated and unwelcome.

\section{Cooptation of exceptional environmental measures in times of crisis}

In States of Exception, Agamben (2005) shows how governments use exceptional historical moments to increase their power by using crises to justify the suspension of constitutional rights and laws and the extension of military power. Similarly, Naomi Klein (2007) argues that capitalists also use large-scale disasters, in what she calls disaster capitalism, to extend their power by creating opportunities for new forms of capital accumulation in such a way that capitalism not only profits from the disaster itself, but from the distraction created by the disaster. In Brazil, Bolsonaro appears to be using crises of extreme forest loss to create opportunities to both extend military powers and to secure opportunities for capital accumulation.

Thus, a sixth strategy that emerged during the COVID-19 pandemic, one that was also visible during the Amazon fires in the summer of 2019, is the use of the precedence of exceptional protective measures to guard against deforestation as justification for increased military presence in sensitive forested areas. The militarization of the Brazilian Amazon is not new and dates back over a century, with various Brazilian governments setting up military forces in the biome to prevent enemy infiltration of the sparsely populated areas, as well as to open opportunities for new extractive practices (de Castro, Van Dijck and Hogenboom 2014; López 2009). However, what is new is the use of forest protection in times of crisis as an excuse to increase military presence in the Amazon. Although Luiz Inácio Lula da Silva (aka Lula) used the military to battle deforestation during his presidency, he did so as part of a robust environmental strategy (Brands 2011). In contrast, the need to protect the forest under Bolsonaro is a direct result of the lack of enforcement of environmental regulations under his administration (BBC News 2019b; Spring and Eisenhammer 2019).

When news of the raging Amazon fires generated global concern in 2019, Bolsonaro sent the army to combat the fires and they remained there until late October (Garcia 2019). Then when Bolsonaro created a new Amazon Council in January 2020, he simultaneously created a new Environmental Police force composed of state military police to support the new Council, also headed by a retired military general, Hamilton Mourão, who openly supports mining development in the Amazon (Rocha 2020). As deforestation increased under the cover of the COVID-19 pandemic with the fire season approaching, Bolsonaro deployed the military to the Amazon in May 2020 by Decree 10.341/2020, three months earlier than in 2019. Importantly, the Decree also put environmental protection of the Amazon under the control of the army. And in October 2020, the newly formed Amazon Council announced that the military would remain in the Amazon until April 2021 (Carvalho 2020). I argue that, although the use of the military to protect the Amazon from foreign infiltration and to expand extractive opportunities has a long history, what is new is that it is being done under a democracy where there should (presumably) be consent. Under military rule, there was no such presumption.

\section{(Not) Weakening protective measures}

In this case, rather than weakening of protective measures, this strategy takes advantage of such measures to secure opportunities for extraction. While the decrees to deploy the military to the Amazon stated, in part, the intent to help combat fires, others believed this to be a smokescreen to further militarize the Amazon as part of a plan to expedite the opening of the biome for extractive industry (Dias 2019). Known as the Barao do Rio Branco Plan, a project proposed by Bolsonaro shortly after taking office would introduce a new hydro-electric dam, bridge, and highway extensions to allow for easier access to areas of the Amazon. The proposed project has drawn wide criticism from socio-environmentalists due to its lack of acknowledgment and/or assessment of potential effects on important biodiversity preserves, indigenous reserves and quilombo communities (D. Phillips 2019a; Rocha 2019) and there has been some indication that the increased militarization of the Amazon is associated with this project (Dias 2019). 
Anti-environmentalist enmity

As stated elsewhere, IBAMA is the Brazilian agency normally charged with monitoring and enforcement of environmental regulations. However, Bolsonaro's 2020 budget included a 25\% cut to IBAMA's forest monitoring programs (Rocha 2020). Additionally, the creation of the Amazon Council and an Environmental Police force staffed by military personnel, as well as Decree 10.341/2020 - which among other things put environmental protection of the Amazon under the control of the army - superseded IBAMA's oversight of deforestation in the Amazon (Bonduki 2020; Soares 2020). By displacing the non-military government officials of IBAMA and defunding its forest monitoring programs, the Bolsonaro administration is simultaneously making a statement that IBAMA is not capable of performing its duties, while also ensuring that they are unable to do so.

\section{Conclusion}

Fisher (2019, p. 384) writes, "(E)nvironmental law engages all the institutional and legal resources of a constitutional democracy to operate-public discourse, expertise, public administration, legislation, accountability, dispute resolution, multi-level governance and much else besides." Bolsonaro is actively removing each of these resources at the national level. Meanwhile, as Brazil's forests continue to suffer from unsustainable levels of deforestation (Silva Junior et al. 2021) and record numbers of fires (Muniz, Fonseca and Ribiero 2020; Watanabe 2020), scientists are predicting that $40 \%$ of the Amazon rainforest could become savannah in the near future unless more is done to combat deforestation and climate change (Staal et al. 2020). It is thus more critical than ever to understand why and how Bolsonaro is accomplishing the dismantling of federal environmental safeguards and institutions. Moreover, while such processes are understood to occur in shifts from "progressive" to authoritarian neoliberalism, there is still a broad gap in analyses on how this shift occurs. This article attempted to narrow this gap by conceptualizing Bolsonaro's anti-environment antics within the broader context of the contemporary authoritarian neoliberal turn.

Following Poulantzas' (1978) analysis of 'authoritarian statism', Bruff (2014, p. 125) describes the 'authoritarian fix' as a restructuring of state institutions to remove barriers to capitalist accumulation. As such, I approach the analysis of Bolsonaro's strategies with the assumption that they aim to remove barriers to capital accumulation. I show how each strategy accomplishes this goal by either weakening environmental measures that place limits on capitalist extraction, or by strengthening measures that can be used to extend military power and expand control over resources for extraction. But Bolsonaro must simultaneously remove the guardians of the protective environmental measures to prevent their return, and I suggest that he accomplishes this by engaging anti-environmentalist enmity to de-legitimize the supporters of environmental regulation. ${ }^{12}$

On a final note, while this article focused on Bolsonaro's far right government, caution is warranted in assigning authoritarianism as it relates to environmental governance as a (strictly) far right phenomenon. Recent explorations of post-political trends indicate that the far right are not alone in removing dissent in favor of unrestrained capitalism. Post-politics, or the yielding of power based on global ideological visions of the world to technocratic expertise (Žižek 1999), is increasingly rearing its head in environmental politics. Fletcher (2014) describes the "orchestrating of consent" to neoliberal agendas in the 2012 International Conservation Congress, where dissent is dispensed with through multiple strategies geared toward creating the illusion of consent to the neoliberal hegemonization of international conservation. With its focus on faith in 'objective' technocratic knowledge as authority, the post-politicization of environmental governance stands in stark contrast to methods of removal of consent by authoritarian neoliberals, which often include post-truth political gaslighting to

\footnotetext{
${ }^{12}$ A theme that runs through many of the articles in this special issue is Foucault's conceptualization of 'biopower' and the tension between life and death. In connection with this theme, the exceptional measures that are being removed in Brazil were arguably put in place to 'make live' certain forms of life that enhance biodiversity and climate stability. By removing such measures and preventing their return via enmity, these lifeforms are essentially being made to 'let die', even to the point of extinction. More than that, it could be argued that these lifeforms will be 'made to die' to make way for other lifeforms to be 'made to live' that support capitalist extraction (e.g. corn, soy, cattle). In this sense, anti-environmentalist enmity is more than just an objective of authoritarian neoliberals such as Bolsonaro. It is also emblematic of the broader enmity of life and death struggles inherent in the struggle for 'biopower.'
} 
systematically extinguish public faith in any 'objective' truth (Neimark et al. 2019). Yet the two accomplish the same foreclosure on any paths forward that do not center on capitalism. Thus, an interesting and important area for future research could include an examination of the confluences and divergences of the two methods with respect to environmental governance.

\section{Bibliography}

Acara, E. 2019. Sequestering a river: the political ecology of the 'dead' Ergene river and neoliberal urbanization in today's Turkey. Annals of the American Association of Geographers 109(2): 422-433.

Acebes, C. M., Wilkinson, D. and Téllez-Chávez, L. 2019. Rainforest mafias: how violence and impunity fuel deforestation in Brazil's Amazon. Human Rights Watch, 17 September, https:/www.hrw.org/report/2019/09/17/rainforest-mafias/how-violence-and-impunity-fueldeforestation-brazils-amazon.

Agamben, G. 2005. State of exception, translated by Kevin Attell. University of Chicago Press.

Amazon Fund. no date. What is the Amazon Fund? http://www.amazonfund.gov.br/en/home/.

Angelo, C. 2019. Cruzada contra o Inpe testa limites do mundo ficcional bolsonarista. El País, 3 August, https://brasil.elpais.com/brasil/2019/08/03/opinion/1564789164_719921.html.

Aos Fatos. 2019. In 10 weeks as president, Jair Bolsonaro made one false statement per day. The Brazilian Report, 13 March, https://brazilian.report/power/2019/03/13/false-statements-bolsonaro/.

Arbex, T. 2019. Supreme court keeps demarcation of Indigenous lands with Indigenous agency. Folha De S.Paulo, 2 August, https://www1.folha.uol.com.br/internacional/en/brazil/2019/08/supreme-court-keepsdemarcation-of-indigenous-lands-with-indigenous-agency.shtml.

Arefin, M. R. 2019. The state, sewers, and security: how does the Egyptian state reframe environmental disasters as terrorist threats? Annals of the American Association of Geographers 109(2): 412-421.

Arsenault, C. 2017. Brazil, home of Amazon, rolls back environmental protection. Reuters, 15 May, https://www.reuters.com/article/us-brazil-politics-environment/brazil-home-of-amazon-rolls-backenvironmental-protection-idUSKCN18B21P.

Assunção, J., Gandour, C. and Rocha, R. 2013. DETERring deforestation in the Amazon: environmental monitoring and law enforcement. Climate Policy Initiative, Núcleo de Avaliaçao de Polıticas Climáticas, Pontifica Universidade Católica (PUC), Rio de Janeiro.

Assunção, J. and Rocha, R. 2019. Getting greener by going black: the effect of blacklisting municipalities on Amazon deforestation. Environment and Development Economics 24(2): 115-137.

Audi, A. and Martins, R. M. 2019. Fiscais batem ponto e recebem salários no meio ambiente de Ricardo Salles - só não podem trabalhar. The Intercept_Brasil, 9 May, https://theintercept.com/2019/05/08/sallesparalisa-meio-ambiente/.

BBC News. 2019a. Amazon fires: fines for environmental crimes drop under Bolsonaro. BBC News, 24 August, https://www.bbc.com/news/world-latin-america-49460022.

BBC News. 2019b. Amazon fires increase by 84\% in one year - space agency. BBC News, 21 August, https://www.bbc.com/news/world-latin-america-49415973.

Bell, E. 2019. Brexit: towards a neoliberal real utopia? Observatoire de la Société Britannique (24): 45-66.

Bell, E. and Christoph, G. 2020. The slow retreat of neoliberalism in contemporary Britain? in Neoliberalism in context. Dawes, S. and Lenormand, N. (Eds.). Springer. Pp. 19-38.

Bogliolo, L. 2019. Law, neoliberal authoritarianism, and the Brazilian crisis. Third World Approaches to International Law Review, 30 August, https://twailr.com/law-neoliberal-authoritarianism-and-thebrazilian-crisis/.

Bolsonaro, J. 2019. Tweets (@jairbolsonaro). $\quad$ Twitter, $26 \quad$ April, https://twitter.com/jairbolsonaro/status/1121713534402990081. 
Bonduki, N. 2020. Bolsonaro uses the quarantine to destroy the environment. Folha De S.Paulo, 19 May, https://www1.folha.uol.com.br/internacional/en/scienceandhealth/2020/05/bolsonaro-uses-thequarantine-to-destroy-the-environment.shtml.

Borba, R. 2020. Disgusting politics: circuits of affects and the making of Bolsonaro. Social Semiotics http://doi.org/10.1080/10350330.2020.1810554

Bragança, D. and Menegassi, D. 2020. Salles sugeriu aproveitar a pandemia para desregulamentar as leis ambientais. Oeco, 22 May, https://www.oeco.org.br/noticias/salles-sugeriu-aproveitar-a-pandemia-paradesregulamentar-as-leis-ambientais/.

Brands, H. 2011. Evaluating Brazilian grand strategy under Lula. Comparative Strategy 30(1): 28-49.

Branford, S. and Borges, T. 2019. Brazil on the precipice: from environmental leader to despoiler (2010-2020). Mongabay, 23 December, https://news.mongabay.com/2019/12/brazil-on-the-precipice-fromenvironmental-leader-to-despoiler-2010-2020/.

Branford, S. and Torres, M. 2021. As climate summit unfolds, no Biden-Bolsonaro Amazon deal forthcoming. Mongabay, 22 April, https://news.mongabay.com/2021/04/as-climate-summit-unfolds-no-bidenbolsonaro-amazon-deal-forthcoming/.

Brenner, N. and Theodore, N. 2002. Cities and the geographies of 'actually existing neoliberalism. Antipode 34(3): 349-379.

Brito, R. 2021. Brazil Supreme Court confirms ruling that judge was biased against Lula. Reuters, 24 June, https://www.reuters.com/world/americas/brazil-supreme-court-confirms-ruling-that-judge-was-biasedagainst-lula-2021-06-23/.

Brown, W. 2020. Neoliberalism's Frankenstein. In Authoritarianism: three inquiries in critical theory. Brown, W., Gordon, P. E., and Pensky, M. (Eds.). University of Chicago Press. 7-44.

Bruff, I. 2014. The rise of authoritarian neoliberalism. Rethinking Marxism 26(1): 113-129.

Bruff, I. and Tansel, C. B. 2019. Authoritarian neoliberalism: trajectories of knowledge production and praxis. Globalizations 16(3): 233-244.

Bruff, I., and Tansel, C. B. (Eds.). 2019. Special issue on authoritarian neoliberalism: philosophies, practices, contestations. Globalizations 16(3).

Cahill, D., Cooper, M., Konings, M., Primrose, D. (Eds.). 2018. The SAGE handbook of neoliberalism. Sage.

Carvalho, D. 2020. Government will keep armed forces in the legal Amazon until April 2021. Folha De S.Paulo, 27 October, https://www1.folha.uol.com.br/internacional/en/scienceandhealth/2020/10/governmentwill-keep-armed-forces-in-the-legal-amazon-until-april2021.shtml?utm_source=newsletter\&utm_medium=email\&utm_campaign=newsen.

Carvalho, W.D., Mustin, K., Hilário, R.R., Vasconcelos, I.M., Eilers, V., Fearnside, P.M. 2019. Deforestation control in the Brazilian Amazon: a conservation struggle being lost as agreements and regulations are subverted and bypassed. Perspectives in Ecology and Conservation 17(3): 122-130.

Casado, L. and Londoño, E. 2019. Under Brazil's far-right leader, Amazon protections slashed and forests fall. New York Times, 28 July, https://www.nytimes.com/2019/07/28/world/americas/brazil-deforestationamazon-bolsonaro.html.

Climainfo. 2019. Desmatamento é recorde sob governo Bolsonaro. Climainfo, 18 November, https://climainfo.org.br/2019/11/18/desmatamento-e-recorde-sob-governo-bolsonaro/.

Coletta, R. Della and Faria, F. 2019. Bolsonaro suffers first Supreme Court defeat. Folha De S.Paulo, 13 June, Available at: https://www1.folha.uol.com.br/internacional/en/brazil/2019/06/bolsonaro-suffers-firstsupreme-court-defeat.shtml.

Cornelissen, L. 2021. Elements of neoliberal Euroscepticism: how neoliberal intellectuals came to support Brexit. British Politics. https://doi.org/10.1057/s41293-020-00155-3

Cowie, S. 2018. Brazil's far-right presidential candidate Jair Bolsonaro is headed for victory on Sunday - and he's bringing his shock troops with him. The Intercept, 5 October, https://theintercept.com/2018/10/05/jair-bolsonaro-brazil-election-stabbinng/. 
Cozzolino, A. 2018. Trumpism as nationalist neoliberalism. A critical enquiry into Donald Trump's political economy. Interdisciplinary Political Studies 4(1): 47-73.

Crooks, K.R., Burdett, C.L., Theobald, D.M., King, S.R.B., Di Marco, M., Rondinini, C., Boitani, L., 2017. Quantification of habitat fragmentation reveals extinction risk in terrestrial mammals. Proceedings of the National Academy of Sciences 114(29): 201705769.

da Silva, A. J. B. and Larkins, E. R. 2019. The Bolsonaro election, antiblackness, and changing race relations in Brazil. The Journal of Latin American and Caribbean Anthropology 24(4): 893-913.

Dawes, S. and Lenormand, M. 2019. Neoliberalism in context: governance, subjectivity and knowledge. Springer Nature.

de Castro, F., Van Dijck, P. and Hogenboom, B. (Eds.). 2014. The extraction and conservation of natural resources in South America: recent trends and challenges. Centre for Latin American Studies and Documentation.

Dias, T. 2019. Operation Amazon redux: Brazil's army wanted to 'occupy' the Amazon before. Leaked audio reveals their plan to try again. The Intercept, 20 September, https://theintercept.com/2019/09/20/amazonbrazil-army-bolsanaro/.

Dwyer, C. 2019. Amazon rainforest sees biggest spike in deforestation in over a decade. $N P R, 18$ November, https://www.npr.org/2019/11/18/780408594/amazon-rainforest-sees-biggest-spike-in-deforestation-inover-a-decade.

Ennes, J. 2021. Timber troubles fell Ricardo Salles, Brazil's environment minister. Mongabay, 24 June, https://news.mongabay.com/2021/06/timber-troubles-fell-ricardo-salles-brazils-environment-minister/.

Escobar, H. 2019a. Bolsonaro's first moves have Brazilian scientists worried. Science 363(6425): 330.

Escobar, H. 2019b. In Brazil, 'useful idiots' protest cuts to research and education. ScienceMag, 17 May, https://www.sciencemag.org/news/2019/05/brazil-useful-idiots-protest-cuts-research-and-education.

Escobar, H. 2020. Deforestation in the Brazilian Amazon is still rising sharply. ScienceMag, 7 August, https://science.sciencemag.org/content/369/6504/613.summary?casa_token=C4xPamCIxv8AAAAA:O HBgfPLnUpZHXUxgZKbkIJ2HGpIfKjDBeILekDanBqkCQzjXhlecmLAVy3lE575EplgIkLZgpj62v9.

Escobar, H. 2021. 'A hostile environment.' Brazilian scientists face rising attacks from Bolsonaro's regime. ScienceMag, 7 April, https://www.sciencemag.org/news/2021/04/hostile-environment-brazilianscientists-face-rising-attacks-bolsonaro-s-regime.

Esteves, B. 2019. The environment as an obstacle: the declared war and the veiled war between the Bolsonaro government and the forces resisting deforestation. Folha De S.Paulo 153, June, https://piaui.folha.uol.com.br/materia/the-environment-as-an-obstacle/

Fabry, A. and Sandbeck, S. 2019a. Introduction to special issue on 'authoritarian neoliberalism'. Competition \& Change 23(2): 109-115.

Fabry, A. and Sandbeck, S. (Eds.). 2019b. Special issue on authoritarian neoliberalism. Competition \& Change 23(2).

Ferrante, L. and Fearnside, P. M. 2019. Brazil's new president and 'ruralists' threaten Amazonia's environment, traditional peoples and the global climate. Environmental Conservation 46(4): 261-263.

Fisher, E. 2019. Unearthing the relationship between environmental law and populism. Journal of Environmental Law 31(3): 383-387.

Fletcher, R. 2014. Orchestrating consent: post-politics and intensification of Nature ${ }^{\mathrm{TM}}$ Inc. at the 2012 World Conservation Congress. Conservation and Society 12(3): 329-342.

Forchtner, B., Kroneder, A. and Wetzel, D. 2018. Being skeptical? Exploring far-Right climate-change communication in Germany. Environmental Communication 12(5): 589-604.

Fox, K. and Lang, M. 2019. Brazil's Bolsonaro says he 'loves' the Amazon. But his policies are designed to wreak havoc on it. CNN, 27 August, https://edition.cnn.com/2019/08/25/americas/brazil-bolsanaroenvironmental-record-intl/index.html.

Fraser, N. 2017. The end of progressive neoliberalism. Dissent 64(2): 130-34. 
Fuchs, C. 2017. Donald Trump: a critical theory-perspective on authoritarian capitalism. tripleC: Communication, Capitalism \& Critique 15(1): 1-72.

Garcia, R. T. 2019. After Brazil's summer of fire, the militarization of the Amazon remains. Foreign Policy, 19 November, https://foreignpolicy.com/2019/11/19/militarization-amazon-legacy-brazil-forest-firebolsonaro/.

Girardi, G. 2019. Gastos com ações de gestão ambiental do País despencam neste ano. Estadão, 11 September, https://sustentabilidade.estadao.com.br/blogs/ambiente-se/gastos-com-acoes-de-gestao-ambiental-dopais-despencam/.

globo.com. 2018. Bolsonaro sinaliza que Meio Ambiente e Agricultura serão ministérios distintos. globo.com, 1 November, https://epocanegocios.globo.com/Brasil/noticia/2018/11/epoca-negocios-bolsonarosinaliza-que-meio-ambiente-e-agricultura-serao-ministerios-distintos.html.

Gonzales, J. 2019. New appointments, new policies don't bode well for Brazilian Amazon. Mongabay, 4 February, https://news.mongabay.com/2019/02/new-appointments-new-policies-dont-bode-well-forbrazilian-amazon/.

Graybill, J. K. 2019. Emotional environments of energy extraction in Russia. Annals of the American Association of Geographers 109(2): 382-394.

Guimarães, D. L. 2021. Brazil's environmental downturn: a tale of many cattle. Chicago Policy Review, 8 January, https://chicagopolicyreview.org/2021/01/08/brazils-environmental-downturn-a-tale-of-manycattle/.

Hall, K., Goldstein, D. M. and Ingram, M. B. 2016. The hands of Donald Trump: entertainment, gesture, spectacle. HAU: Journal of Ethnographic Theory 6(2): 71-100.

Harris, B. and Schipanii, A. 2019. Bolsonaro fights lawmakers turning him into 'Queen of England'. Financial Times, 1 July.

Holmes, G. and Cavanagh, C. J. 2016. A review of the social impacts of neoliberal conservation: formations, inequalities, contestations. Geoforum 75: 199-209.

Hunter, W. and Power, T. J. 2019. Bolsonaro and Brazil's illiberal backlash. Journal of Democracy 30(1): 6882.

Jung, S. et al. 2017. Brazil's national environmental registry of rural properties: implications for livelihoods. Ecological Economics 136: 53-61.

Kantel, A. J. 2019. Fishing for power: incursions of the Ugandan authoritarian state. Annals of the American Association of Geographers 109(2): 443-455.

Kaul, N. 2021. The misogyny of authoritarians in contemporary democracies. International Studies Review https://doi.org/10.1093/isr/viab028

Kellner, D. 2016. American nightmare: Donald Trump, media spectacle, and authoritarian populism. Springer.

Klein, N. 2007. The shock doctrine: the rise of disaster capitalism. Macmillan.

Le Billon, P. 2021. Crisis conservation and green extraction: biodiversity offsets as spaces of double exception. Journal of Political Ecology 28(1): 864-888.

Lehman, S. 2018. A look at offensive comments by Brazil candidate Bolsonaro. AP News, 29 September, https://apnews.com/article/1f9b79df9b1d4f14aeb1694f0dc13276.

Lockwood, M. 2018. Right-wing populism and the climate change agenda: exploring the linkages. Environmental Politics 27(4): 712-732.

Londoño, E. and Casado, L. 2019. With Amazon on fire, environmental officials in open revolt against Bolsonaro. New York Times, 28 August, https://www.nytimes.com/2019/08/28/world/americas/amazonfires-brazil.html.

López, A. 2009. The Brazilian Amazon in an environmental security and social conflict framework. In Facing Global Environmental Change. Günter, H., Spring, U. O., Grin J., Mesjasz, C. Kameri-Mbote, P., Behera, N. C., Chourou, B. and Krummenacher, H. (Eds.). Springer 915-924. 
McCarthy, J. (ed.). 2019. Special issue on environmental governance in a populist/authoritarian era. Annals of the American Association of Geographers 109(2).

McCarthy, J. 2019. Authoritarianism, populism, and the environment: comparative experiences, insights, and perspectives. Annals of the American Association of Geographers 109(2): 301-313.

Mudde, C. 2019. The Far Right today. Wiley.

Mullenite, J. 2019. Infrastructure and authoritarianism in the land of waters: a genealogy of flood control in Guyana. Annals of the American Association of Geographers 109(2): 502-510.

Muniz, B., Fonseca, B. and Ribiero, R. 2020. Fires raze nearly half of Indigenous territories in Brazil's Pantanal. Mongabay, 6 October, https://news.mongabay.com/2020/10/fires-raze-nearly-half-of-indigenousterritories-in-brazils-pantanales/.

Myers, N., Mittermeier, R.A., Mittermeier, C.G., Da Fonseca, G.A.B., Kent, J. 2000. Biodiversity hotspots for conservation priorities. Nature 403(6772): 853.

Neimark, B., Childs, J., Nightingale, A.J., Cavanagh, C.J., Sullivan, S., Benjaminsen, T.A., Batterbury, S.P.J., Koot, S., Harcourt, W. 2019. Speaking power to 'post-truth': critical political ecology and the new authoritarianism. Annals of the American Association of Geographers 109(2): 613-623.

Nugent, C. 2021. Brazil's controversial environment minister has quit. What does it mean for the Amazon? Time, 24 June, https://ime.com/6075506/ricardo-salles-quits-amazon/.

Observatório do Clima. 2020. The worst is yet to come. Observatório do Clima, 10 January, https://www.oc.eco.br/wp-content/uploads/2020/01/Relato\%CC\%81rio-COP25-Ajustes-v3.pdf.

Paviolo, A., De Angelo, C., Ferraz, K.M., Morato, R.G., Pardo, J.M., Srbek-Araujo, A.C., de Mello Beisiegel, B., Lima, F., Sana, D., Da Silva, M.X. 2016. A biodiversity hotspot losing its top predator: the challenge of jaguar conservation in the Atlantic Forest of South America. Scientific Reports 6(1): 1-16.

Peck, J. 2001. Neoliberalizing states: thin policies/hard outcomes. Progress in Human Geography 25(3): 445455.

Peck, J. 2013. Explaining (with) neoliberalism. Territory, Politics, Governance 1(2): 132-157.

Peck, J. and Theodore, N. 2019. Still neoliberalism? South Atlantic Quarterly 118(2): 245-265.

Pettorelli, N.W., Barlow, J., Cadotte, M.W., Lucas, K., Newton, E., Nuñez, M.A., Stephens, P.A. 2019. Applied ecologists in a landscape of fear. Journal of Applied Ecology 56: 1034-1039.

Phillips, D. 2019a. Bolsonaro declares Brazil's 'liberation from socialism' as he is sworn in. The Guardian, 1 January, https://www.theguardian.com/world/2019/jan/01/jair-bolsonaro-inauguration-brazil-president.

Phillips, D. 2019b. Jair Bolsonaro launches assault on Amazon rainforest protections. The Guardian, 2 January, https://www.theguardian.com/world/2019/jan/02/brazil-jair-bolsonaro-amazon-rainforest-protections.

Phillips, D. 2020. 'The playbook is the American alt-right': Bolsonaristas follow familiar extremist tactics. The Guardian, 27 January, https://www.theguardian.com/world/2020/jan/27/american-alt-right-playbookbolsonaro-extremist-tactics-brazil.

Phillips, T. 2019. Jair Bolsonaro claims 'profound love' for Amazon rainforest as criticism intensifies. The Guardian, 24 August, https://www.theguardian.com/environment/2019/aug/24/jair-bolsonaro-claimsprofound-love-for-amazon-rainforest-as-criticism-fires-intensifies.

Poulantzas, N. 1978. State, power, socialism. New Left Books.

Pulido, L., Bruno, T., Faiver-Serna, C., Galentine, C. 2019. Environmental deregulation, spectacular racism, and White Nationalism in the Trump Era. Annals of the American Association of Geographers 109(2): 520-532.

Puthuparambil, S. 2019. Satellite imagery combats eco-destructive activity in the Amazon. Berkeley Scientific Journal 23(2).

Rachman, G., Blasina, N. and Schipani, A. 2019. Brazil's Jair Bolsonaro pledges to open up economy. Financial Times, 22 January. 
Redden, E. 2019. In Brazil, a hostility to academe. Inside Higher Ed, 6 May, https://www.insidehighered.com/news/2019/05/06/far-right-government-brazil-slashes-universityfunding-threatens-cuts-philosophy-and.

Reuters. 2021. Bolsonaro slashes Brazil's environment budget, day after climate talks pledge. The Guardian, 24 April, https://www.theguardian.com/world/2021/apr/24/bolsonaro-slashes-brazils-environmentbudget-day-after-climate-talks-pledge.

Rocha, J. 2019. Bolsonaro government reveals plan to develop the 'Unproductive Amazon'. Amazonia Socioambiental 28 January, https://www.amazoniasocioambiental.org/en/radar/bolsonaro-governmentrev,eals-plan-to-develop-the-unproductive-amazon/.

Rocha, J. 2020. Brazil's Bolsonaro creates Amazon Council and Environmental Police force. Mongabay, 24 January, $\quad$ https://news.mongabay.com/2020/01/brazils-bolsonaro-creates-amazon-council-andenvironmental-police-force/.

Romm, J. 2019. 'Poop every other day' to save Earth says Brazilian president as he destroys the Amazon. Think Progress, 13 August, https://archive.thinkprogress.org/poop-every-other-day-to-save-earth-saysbrazilian-president-as-he-destroys-the-amazon-8ebcfa298ed1/.

Rydgren, J. (ed.). 2018. The Oxford handbook of the radical right. Oxford University Press.

Saad-Filho, A. 2018. Privilege versus democracy in Brazil. Jacobin Magazine, October, https://jacobinmag.com/2018/10/brazil-election-bolsonaro-haddad-lula-pt-democracy.

Saad-Filho, A. and Boffo, M. 2020. The corruption of democracy: corruption scandals, class alliances, and political authoritarianism in Brazil. Geoforum 124: 300-329.

Schipanii, A. and Harris, B. 2019. Brazil minister calls for the Amazon to be monetised. Financial Times, 23 August.

Silva Junior, C.H.L., Pessôa, A.C.M., Carvalho, N.S., Reis, J.B.C., Anderson, L.O., Aragão, L.E.O.C. 2021. The Brazilian Amazon deforestation rate in 2020 is the greatest of the decade. Nature Ecology \& Evolution 5(2): 144-145.

Soares, E. 2020. Brazil: government creates Amazon Council to protect Amazon region. Library of Congress, 19 February, https://www.loc.gov/law/foreign-news/article/brazil-government-creates-amazon-councilto-protect-amazon-region/.

Spring, J. 2019a. Brazil judge blocks transfer of indigenous land decisions to farm ministry. Reuters, 25 June, https://www.reuters.com/places/brazil/article/us-brazil-politics-indigenous/brazil-judge-blocks-transferof-indigenous-land-decisions-to-farm-ministry-idUSKCN1TP2V7.

Spring, J. 2019b. Ex-ministers blast Bolsonaro for dismantling Brazil's environment protections. Reuters, 8 May, $\quad$ https://www.reuters.com/article/us-brazil-environment/ex-ministers-blast-bolsonaro-fordismantling-brazils-environment-protections-idUSKCN1SE2IQ.

Spring, J. and Eisenhammer, S. 2019. Exclusive: As fires race through Amazon, Brazil's Bolsonaro weakens environment agency. Reuters, 28 August, https://www.reuters.com/article/us-brazil-environment-ibamaexclusive-idUSKCN1VI14I.

Staal, A., Fetzer, I., Wang-Erlandsson, L., Bosmans, J.H.C., Dekker, S.C., van Nes, E.H., Rockström, J., Tuinenburg, O.A. 2020. Hysteresis of tropical forests in the 21st century. Nature Communications 11(1): $1-8$.

Stargardter, G. 2019. Bolsonaro presidential decree grants sweeping powers over NGOs in Brazil. Reuters, 2 January, https://www.reuters.com/article/us-brazil-politics-ngos/bolsonaro-presidential-decree-grantssweeping-powers-over-ngos-in-brazil-idUSKCN1OW1P8.

Tarrow, S. G. 2011. Power in movement: social movements and contentious politics. Cambridge University Press.

Taylor, C. 2019. Fires in Brazil's Amazon rainforest surged by 84\% this year, space agency says. CNBC, 21 August, https://www.cnbc.com/2019/08/21/fires-in-brazils-amazon-rainforest-up-84percent-this-yearspace-agency.html. 
The Associated Press. 2019. Brazil's Senate rejects Bolsonaro's gun decree. AP News, 20 June, https://apnews.com/article/df8cf3f86c6f43b2bea79c0266f2ad4b.

Tollefson, J. 2018. Brazil's new president adds to global threat to science. Nature 563: 5-6.

Tollefson, J. 2019. 'Tropical Trump' sparks unprecedented crisis for Brazilian science. Nature News, 1 August, https://www.nature.com/articles/d41586-019-02353-6.

Trinkunas, H. 2014. Brazil's rise: seeking influence on global governance. Latin America Initiative, Foreign Policy at Brookings.

Uribe, G. 2020. Ministro do Meio Ambiente defende aproveitar crise do coronavírus para 'passar a boiada'. Folha De S.Paulo, 22 May, https://www1.folha.uol.com.br/ambiente/2020/05/ministro-do-meioambiente-defende-aproveitar-crise-do-coronavirus-para-passar-a-boiada.shtml.

Uribe, G., Coletta, R. Della and Moreira, M. 2019. Bolsonaro diz que desmatamento é cultural no Brasil e não acabará. Folha De S.Paulo, 20 November, https://www1.folha.uol.com.br/ambiente/2019/11/bolsonarodiz-que-desmatamento-e-cultural-no-brasil-e-nao-acabara.shtml.

Vaughan, A. 2019. Amazon deforestation officially hits highest level in a decade. New Scientist, 18 November, https://www.newscientist.com/article/2223798-amazon-deforestation-officially-hits-highest-level-in-adecade/?utm_campaign=Carbon Brief Daily Briefing\&utm_medium=email\&utm_source=Revue newsletter.

Viscidi, L. and Graham, N. 2019. Brazil was a global leader on climate change. Now it's a threat. ForeignPolicy, 4 January, https://foreignpolicy.com/2019/01/04/brazil-was-a-global-leader-on-climate-change-now-itsa-threat/.

Voiland, A. 2019. Tracking Amazon deforestation from above. NASA Earth Observatory, December, https://earthobservatory.nasa.gov/images/145988/tracking-amazon-deforestation-from-above.

Watanabe, P. 2020. Amazon already hit by more fires in 2020 than in all of last year. Folha De S.Paulo, 26 October, https://www1.folha.uol.com.br/internacional/en/scienceandhealth/2020/10/amazon-already-hitby-more-fires-inn-2020-than-in-all-of-lastyear.shtml?utm_source=newsletter\&utm_medium=email\&utm_campaign=newsen.

Wilkinson, D. S. and B. 2018. Judge orders arrest of ex-Brazil president Lula da Silva. CNN, 5 April, https://edition.cnn.com/2018/04/05/americas/brazil-lula-ruling-corruption-election-intl/index.html.

Wraight, T. 2019. From Reagan to Trump: the origins of US neoliberal protectionism. The Political Quarterly 90(4): 735-742.

Žižek, S. 1999. The ticklish subject: the absent centre of political ontology. Verso. 